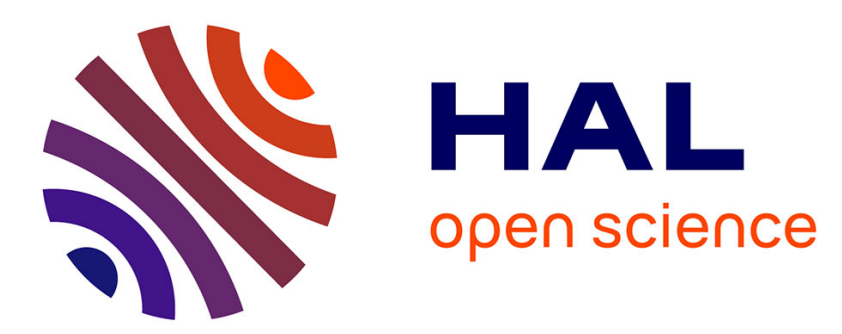

\title{
Alkylation of manganese(ii) tetraphenylporphyrin by a synthetic antimalarial trioxane
}

Jean-François Berrien, Olivier Provot, Joëlle Mayrargue, Michel Coquillay, Liliane Cicéron, Frederick Gay, Martin Danis, Anne Robert, B. Meunier

\section{- To cite this version:}

Jean-François Berrien, Olivier Provot, Joëlle Mayrargue, Michel Coquillay, Liliane Cicéron, et al.. Alkylation of manganese(ii) tetraphenylporphyrin by a synthetic antimalarial trioxane. Organic \& Biomolecular Chemistry, 2003, 1 (16), pp.2859. 10.1039/b302835f . hal-02394634

\section{HAL Id: hal-02394634 \\ https://hal.science/hal-02394634}

Submitted on 4 Dec 2019

HAL is a multi-disciplinary open access archive for the deposit and dissemination of scientific research documents, whether they are published or not. The documents may come from teaching and research institutions in France or abroad, or from public or private research centers.
L'archive ouverte pluridisciplinaire HAL, est destinée au dépôt et à la diffusion de documents scientifiques de niveau recherche, publiés ou non, émanant des établissements d'enseignement et de recherche français ou étrangers, des laboratoires publics ou privés. 


\section{Alkylation of manganese(II) tetraphenylporphyrin by a synthetic antimalarial}

\section{trioxane}

Jean-François Berrien ${ }^{\mathrm{a}}$, Olivier Provot ${ }^{\mathrm{a}}$, Joëlle Mayrargue ${ }^{\mathrm{a}} *$ Michel Coquillay $^{\mathrm{b}}$,

Liliane Cicéron ${ }^{\mathrm{c}}$, Frédérick Gay ${ }^{\mathrm{c}}$, Martin Danis ${ }^{\mathrm{c}}$, Anne Robert $^{\mathrm{d}}$, Bernard Meunier ${ }^{\mathrm{d}}$ *

${ }^{a}$ UMR 8076 BioCIS, Faculté de Pharmacie, rue J.-B. Clément, F-92296 Châtenay-Malabry Cedex, France. E-mail : Joelle.Mayrargue@ chimorg.u-psud.fr

${ }^{b}$ Laboratoire de Physique, Faculté de Pharmacie, rue J.-B. Clément, F-92296 Châtenay-Malabry Cedex, France.

${ }^{c}$ INSERM U511, Immuno-biologie cellulaire et moléculaire des infections parasitaires, Groupe hospitalier Pitié-Salpêtrière, F-75013 Paris, France.

${ }^{d}$ Laboratoire de Chimie de Coordination du CNRS, 205, route de Narbonne, 31077 Toulouse Cedex 4, France.

Abstract : The synthesis and the antimalarial activity of a new kind of polycyclic 1,2,4-trioxanes are reported. The alkylation of the heme model $\mathrm{Mn}^{\mathrm{II}} \mathrm{TPP}$ by the biologically active (IC $50=320 \mathrm{nmolL}^{-1}$ ) hemiperketal $\mathbf{2}$ is presented. 


\section{Introduction}

Two billion people are now exposed to the risk of malaria and 1 to 3 million die each year from this disease, due to the increasing resistance of the parasite Plasmodium falciparum to the classical drug chloroquine ${ }^{1,2}$ During malaria infection, free heme is liberated in the parasite food vacuole by digestion of the host hemoglobin and then polymerized to malaria pigment. ${ }^{3}$ Heme is therefore an attractive pharmacological target, since it comes from a metabolic pathway that is unique for infected erythrocytes.

Artemisinin 1, a peroxide-containing drug extracted from the chinese plant Artemisia annua $L$. is very efficient against multidrug resistant strains and no case of clinical resistance has been reported up to now despite more than 20 years of intensive use in Asia. ${ }^{2}$ The possible reactivity of artemisinin with heme has been considered as a key factor of its pharmacological activity, ${ }^{4,5}$ and the alkylation of heme $^{6}$ or proteins was observed after incubation of pharmacologically relevant concentrations of artemisinin derivatives in cultured parasites. ${ }^{7}$ We have reported the in vitro alkylation of manganese tetraphenylporphyrin used as a heme model by a C-centred radical derived from artemisinin or other pharmacologically active trioxanes. ${ }^{8-10}$ Covalent adducts heme-artemisinin have also been characterized. ${ }^{11}$

In this article, we report the simple access to new kind of 1,2,4-trioxanes, their antimalarial activities and the alkylation of the heme model $\mathrm{Mn}^{\mathrm{II}} \mathrm{TPP}$ by the trioxane 2 .

\section{Results and Discussion}

\section{Syntheses}

We envisaged a simple access to the polycyclic 1,2,4-trioxane $\mathbf{2}$ (scheme 1) which could be compare with two antimalarial and natural 1,2,4-trioxanes: artemisinin $\mathbf{1}$ and the peroxide $\mathbf{3}$ isolated from the fruit of Amomum krervanh Pierre ${ }^{12}$ (cardamom). The hetero Diels-Alder dimer 6 of methylene cyclohexanone $5,{ }^{13}$ was known to add water in acidic media to give the polycyclic hemiacetal 7 (Scheme 2) ${ }^{14}$ We thought that hydrogen peroxide could react with the dimer $\mathbf{6}$ in the same manner leading to a polycyclic peroxide. In fact, acidic $30 \%$ aqueous hydrogen peroxide in methanol converts 6 into the trioxane $\mathbf{2}$ and two others compounds, presumably diastereomers in a $46 \%$ yield. The major 
one could be obtained in a pure form after careful chromatography and cristallisation. Its structure was determined by $\mathrm{X}$ ray diffraction (vide infra). The water addition product 7 was also isolated from the reaction mixture but in only $4 \%$ yield (scheme 2 ). One can note that the reaction gave about ten times more hydrogen peroxide addition product 2 than water addition product 7. However, in the reaction medium, water was more than four times more concentrated than hydrogen peroxide. This result, can be attributed to the $\alpha$ effect on $\mathrm{H}_{2} \mathrm{O}_{2}$ that makes the oxygen atom of hydrogen peroxide more nucleophilic ${ }^{15}$ than that of $\mathrm{H}_{2} \mathrm{O}$. We wanted to prepare the trioxane 12, a pinenic analogue of $\mathbf{2}$ with a structure close to cardamom peroxide (scheme 3). Unfortunately, cedronellone 11, a natural product isolated from Cedronella canariensis ${ }^{16}$ which was prepared by hetero Diels-Alder dimerization of $d$ pinocarvone $\mathbf{1 0}^{17}$, did not react with $\mathrm{H}_{2} \mathrm{O}_{2}$ under these conditions. These results could be attributed to the low reactivity of the hindered carbonyl function of cedronellone. Moreover, heating reactions with cedronellone and $\mathrm{H}_{2} \mathrm{O}_{2}$ in sulphuric acid gave only tarry materials.

Recently, acyclic $\alpha$-methoxy-substituted dialkyl peroxides $^{18}$ and $\alpha$-methoxyprop-2-yl peroxides derivatives ${ }^{19}$ have been reported for their powerful antimalarial activity. In this way and in order to establish structure-activity relationships, two compounds were synthesized from peroxide $\mathbf{2}$. To obtain peroxides with a different structure, the hydroxyl function of trioxane $\mathbf{2}$ was substituted by two groups with different electronic effects. Thus, the acetate 8 was prepared with $\mathrm{Ac}_{2} \mathrm{O}$, pyridine and using $\mathrm{DMAP}^{20}$ as the hydroxyl function was hindered. The methyl perketal 9 was also synthesized from trioxane 2 using $t$-BuOK and subsequent methylation of the so-formed oxanion with MeI (scheme 2). In our case, deprotonation using $n$-BuLi as previously reported for 3-hydroxy-1,2-dioxolanes gave poor results. ${ }^{21}$ Moreover, classical methods of perketal formation from hemiperketal $\left(\mathrm{MeOH}, \mathrm{HCl} ;{ }^{21} \mathrm{MeOH}\right.$, $\mathrm{TsOH}^{22}$ ) did not provide the desired product.

\section{X-Ray analysis of trioxane 2}

The molecular structure of the title compound is shown in scheme 4. Selected angles are listed in table 2. The molecule consists of four fused rings of single bonded atoms. The bond lengths have standard values: [1.513-1.538 $\AA$ ] for C-C and [1.429-1.465 $\AA]$ for C-O and O-O. Most of angles are in the range $\left[108.1-113.9^{\circ}\right]$ except those listed in table 1 . There is an intermolecular H-bond between the hydroxyl of any molecule with the $\mathrm{O}(4)$ of the next $b$-translated molecule $[\mathrm{O}(17)-\mathrm{H} \ldots \mathrm{O}(4), 3.035 \AA]$. All other 
contributions to the packing cohesion are van der Waals interactions. The molecular conformation is rigidly fashioned because of the $\mathrm{sp}^{3}$ hybridisation of atoms so that we can expect a low molecular compliance under the packing constraints as suggested by the medium value of density $\left(1.293 \mathrm{~g} \mathrm{~cm}^{-3}\right)$ and the low intensity of the intermolecular H-bond. The graphical examination of the region surrounding the peroxide shows that the local accessible surface including $\mathrm{O}(1), \mathrm{O}(2)$ and the next hydrogen $\mathrm{H}$, is almost planar so that there is no steric hindrance for an attack of peroxide.

\section{Antimalarial activity}

Trioxanes 2, 8 and 9 were evaluated in vitro against Plasmodium falciparum (Table 1). The hemiperketal 2 had a substantial activity with $1 / 80$ of the antimalarial potency of artemether on the $P$. falciparum " $\mathrm{H}^{\text {"23 }}$ strain. The cardamom peroxide 3 had one tenth activity of that of artemisinine $\mathrm{e}^{12}$ and roughly one fortieth of that of artemether. So, the antimalarial activities of the natural peroxide $\mathbf{3}$ and $\mathbf{2}$ are comparable even if other synthetic 1,2,4-trioxanes have a better, in vitro activity ${ }^{24}$. Since the latter showed an interesting activity, its substituted derivatives $\mathbf{8}$ and $\mathbf{9}$ were inactive in the range of concentration tested. Examination of the molecular structure of these inactive trioxanes could explain the biological results. As we have recently published for substituted trioxanes ${ }^{25}$, we suppose that compounds 8 and $\mathbf{9}$ could not approach the iron-heme nucleus because of steric hindrance. The Fentontype cleavage of the peroxide moiety, which affords primarily oxyl radicals, is inefficient and compounds are devoid of activity. Moreover, we can suppose that the only compound $\mathbf{2}$ thanks its hydroxyl substituent to coordinate with heme by hydrogen bonding unlike methoxy and acetoxy compounds 8 and 9.

Reaction of the trioxane 2 with Mn"ITPP. As a model of the possible reaction of the antimalarial agent 2 with the intraparasitic heme, we investigated the activation of 2 with manganese(II) tetraphenylporphyrin generated in situ from $\mathrm{Mn}^{\mathrm{III}}(\mathrm{TPP}) \mathrm{Cl}$ and borohydride. The reaction conditions were similar to that previously reported for the alkylation of $\mathrm{Mn}^{\mathrm{II}} \mathrm{TPP}$ by artemisinin, artemether, and several synthetic antimalarial endoperoxides. ${ }^{8-10}$ This reaction produced, after demetallation of the macrocycle under mild conditions, a mixture of the chlorin- and porphyrin adducts $15 \mathrm{C}$ and $\mathbf{1 5 P}$, respectively, containing the main fragment of compound 2 (Scheme 5). The chlorin adduct was the 
major one, as supported by UV-vis spectroscopy, the band at $652 \mathrm{~nm}$ having a relative intensity of $11 \%$ with respect to the Soret band (15\% are expected for a pure chlorin). This indicated a ratio chlorin/porphyrin close to $80 / 20$. The mass spectrometry analysis of the mixture $\mathbf{1 5 C}+\mathbf{1 5 P}$ exhibited molecular peaks at $m / z=853\left(\mathrm{MH}^{+}\right.$for $\left.15 \mathrm{C}\right)$ and $851\left(\mathrm{MH}^{+}\right.$for $\left.15 \mathrm{P}\right)$, corresponding to the substitution of one proton of tetraphenylchlorin or tetraphenylporphyrin, respectively, by a drug-derived fragment without extensive degradation of both partners. The relative abundances of $853 / 851$ was $84 / 16$, consistent with the UV-vis analysis, indicating that $15 \mathrm{C}$ and $15 \mathrm{P}$ have similar behavior under the MS conditions (allowing, in this peculiar conditions, quantitative comparison of mass peaks).

All attempts to separate 15C and 15P by column chromatography or by preparative TLC failed. We therefore decided to oxidize the mixture $15 \mathrm{C}+\mathbf{1 5 P}$ by 2,3-dichloro-5,6dicyanobenzoquinone, in order to isolate and characterize the pure porphyrin adduct 15P. The ${ }^{1} \mathrm{H}$ NMR analysis of pure 15P (less than $1 \mathrm{~mol} \%$ of remaining $15 \mathrm{C}$ ) thus obtained exhibited seven $\beta$-pyrrolic protons, confirming the monoalkylation of the porphyrin macrocycle at a $\beta$-pyrrolic position. Six of the $\beta$-pyrrolic resonances appeared as doublets $\left(1 \mathrm{H}\right.$ each, $\left.{ }^{3} J=5 \mathrm{~Hz}\right)$, and one as a broad singlet corresponding to $\mathrm{H}^{\prime}$ ( $8.86 \mathrm{ppm}$ ), adjacent to the alkylated carbon $\mathrm{C}^{\prime}$. The proton $\mathrm{H} 10 \mathrm{a}$ was detected at $3.63 \mathrm{ppm}$, and two different intracyclic $\mathrm{N} H$ resonances were detected at -2.86 and $-2.67 \mathrm{ppm}$. However, this analysis performed at $250 \mathrm{MHz}$, did not allow individual attribution of the 20 methylene protons that appeared as an unresolved pattern between 2.63 and $1.20 \mathrm{ppm}$. Full assignment of these methylene protons was performed at $500 \mathrm{MHz}$ on the mixture $15 \mathrm{P}+15 \mathrm{P}-\boldsymbol{d}$, and is described in the corresponding paragraph.

The formation of $15 \mathrm{P}$ and $\mathbf{1 5 C}$ can be explained by the following mechanism: the reductive activation of the peroxide bond of $\mathbf{2}$ gave rise to the alkoxy radical centred at $\mathrm{O} 2 \mathbf{1 3}$, followed by $\beta$ scission of the $\mathrm{C} 3-\mathrm{C} 10 \mathrm{a}$ bond to form the $\mathrm{C}$-centred radical 14 . This reactive radical species generated just above the metalloporphyrin ring was able to intramolecularly alkylate a $\beta$-pyrrolic position of the macrocycle at $\mathrm{C}^{\prime}$, generating a $\mathrm{C}$-centred radical at the adjacent position $\mathrm{C} 3$ ' (structure not shown). An intramolecular electron transfer from C3" to the manganese(III) resulted in a manganese(II) complex with a carbocation centred at $\mathrm{C}^{\prime}$. This cationic species can be trapped by the borohydride (initially present in the reaction mixture to reduce the metal centre of $\left.\mathrm{Mn}^{\mathrm{III}}(\mathrm{TPP}) \mathrm{Cl}\right)$, leading to a chlorin 
macrocycle. After demetallation of the complex, the chlorin-type adduct 15C was obtained (for a mild demetallation method, see ref. $8 \mathrm{~b}$ ). As a competitive reaction, the manganese(II) $-\mathrm{C} 3^{1+}$ can lose a proton at $\mathrm{C} 2$ ' to generate, after removal of manganese, the porphyrin adduct 15P. Both reaction pathways were observed. It should be mentioned that the attack of the radical C10a onto a beta-pyrrolic position (which is in fact an intramolecular reaction) is probably more rapid than the rotation of this radical, leading to retention of configuration at C10a. The stereoselectivity of this alkylation of MnTPP by an antimalarial trioxane has recently been documented ${ }^{9}$.

In order to confirm this mechanism, a similar reaction was made in the presence of borodeuteride instead of borohydride. As expected, the alkylation step produced a mixture of chlorin (major) and porphyrin adducts, and the subsequent oxidation by DDQ produced a mixture of porphyrin adducts bearing at $\mathrm{C}^{\prime}$ either a hydrogen atom $\left[\mathbf{1 5 P}, m / z=851\left(\mathrm{MH}^{+}\right)\right]$, or a deuterium atom $(\mathbf{1 5 P}-\boldsymbol{d}$, $\left.m / z=852\left(\mathrm{MH}^{+}\right)\right]\left(\right.$Scheme 6). In the ${ }^{1} \mathrm{H}$ NMR spectrum, the intensity of H3' (8.82 ppm) was $0.9 \mathrm{H}$, indicating partial incorporation of deuterium from $\mathrm{BD}_{4}{ }^{-}$at $\mathrm{C} 3$ ', with a molar ratio $\mathbf{1 5 P} / \mathbf{1 5 P}-\boldsymbol{d}$ of $9 / 1$ (the ratio $15 \mathrm{P} / 15 \mathrm{P}-\boldsymbol{d}$ calculated from MS analysis was $86 / 14$. Owing to the precision of these analyses, both results should be considered as consistent).

It has been previously reported for similar reaction dealing with artemisinin that the trapping of the manganese(II)-C $3^{\prime+}$ species by borodeuteride resulted in the incorporation of a deuterium atom at $\mathrm{C}^{\prime}$ in trans position with respect to the drug-derived fragment (15C-d, Scheme 6). ${ }^{8 b}$ The quinonemediated oxidation of $15 \mathrm{C}-\boldsymbol{d}$ can in principle be made by removal of $\mathrm{HD}$, producing the porphyrin 15P, or by removal of $\mathrm{H}_{2}$, producing the porphyrin 15P- $\boldsymbol{d}$. In the case of the artemisinintetraphenylporphyrin adduct, the artemisinin fragment was connected to the macrocycle via a long $\left(\mathrm{CH}_{2}\right)_{2}-$ arm and did not disturb an extensive $\pi$-stacking between the chlorin and the quinone residues allowing a statistic removal of $\mathrm{HD}$ and $\mathrm{H}_{2}$, and thus formation of equimolecular amounts of porphyrin adducts bearing $\mathrm{H}$ or $\mathrm{D}$ at $\mathrm{C} 3$ '. In the present case, the drug fragment was bound to the $\beta$-pyrrolic position via a secondary carbon that belongs itself to a macrocycle. The upper face of the chlorin was therefore too crowded to accomodate a quinone stacking, consequently the removal of HD (lower face) was favored, leading to the porphyrin $15 \mathrm{P}$ as main product.

The porphyrin adduct 15P has been completely characterized (as a mixture 90/10 with 15P-d) 
using different NMR sequences, particularly NOE correlations were obtained between C10a (3.53 ppm) and $\mathrm{H}^{\prime}(8.82 \mathrm{ppm})$ on one hand, and between $\mathrm{C} 10 \mathrm{a}(3.53 \mathrm{ppm})$ and a meso-phenyl, thus confirming that the alkylation of the porphyrin was obtained by a C10a-centred radical derived from the drug. It should be mentioned that a $\beta$-scission from the alkoxy radical $\mathbf{1 3}$, Scheme 5 , may also produce a primary alkyl radical centred at $\mathrm{C} 7$ by cleavage of the $\mathrm{C} 3-\mathrm{C} 7$ bond. In fact, this route was not observed and such a radical was not trapped.

In addition, we were surprised to isolate a compound bearing a ketone at $\mathrm{C} 6$, instead of the corresponding alcohol, from a reaction mixture containing borohydride. In fact the low reactivity of a ketone located in $\alpha$-position of a spiro-carbon with respect to sodium borohydride has already been reported. ${ }^{26}$

\section{Experimental Section}

Materials. Tetrahydrofuran (THF) was distilled from sodium/benzophenone ketyl. 4Dimethylaminopyridine (DMAP) and pyridine were distilled from potassium hydroxide under argon prior to use. Hydrogen peroxide, $30 \%\left(\mathrm{H}_{2} \mathrm{O}_{2}\right)$ was supplied by Acros. Dichloromethane (stabilized with amylene) and hexane were supplied by Fluka, and had a low content of evaporation residue ( $\leq$ $0.0005 \%$ ). The tetra- $n$-butylammonium borodeuteride was prepared by reaction of tetra- $n$ butylammonium chloride with sodium borodeuteride $98 \% \mathrm{D}$. Isotopic purity of $n \mathrm{Bu}_{4} \mathrm{~N}^{+} \mathrm{BD}_{4}{ }^{-}$was $97 \% \mathrm{D}$ (determined by NMR).

\section{Antimalarial tests}

Antimalarial activity against " $\mathrm{H}$ " chloroquine-sensitive $\operatorname{strain}^{23,27}$ of Plasmodium falciparum was determinated by measuring the incorporation of $\left[{ }^{3} \mathrm{H}\right]$ hypoxanthine by the method of Desjardins ${ }^{28}$. Only slight modifications were introduced: the parasite cultures with an initial parasitaemia of $0.5 \%$ in a $1.8 \%$ erythrocyte-suspension were incubated for 48 hours.

Instrumentation. IR spectra were recorded on a Perkin-Elmer 841 spectrometer. ${ }^{1} \mathrm{H}$ and ${ }^{13} \mathrm{C}$ NMR 
spectra of compounds 2, 6, and 7 were measured with a Bruker ARX $400(400 \mathrm{MHz}$ and $100.6 \mathrm{MHz}$, for ${ }^{1} \mathrm{H}$ and ${ }^{13} \mathrm{C}$, respectively). ${ }^{1} \mathrm{H}$ chemical shifts are reported in ppm from an internal standard TMS or of residual chloroform $(7.27 \mathrm{ppm}) \cdot{ }^{13} \mathrm{C}$ chemical shifts are reported in ppm from the central peak of deuteriochloroform (77.1). NMR characterization of adduct 15P was performed on a Bruker DMX500 spectrometer equipped with a $5 \mathrm{~mm}$ probe operating at $500.13 \mathrm{MHz}$ for ${ }^{1} \mathrm{H}$. The signal assignment was made with the help of 2D TOCSY (mixing time $60 \mathrm{~ms}$ ), 1D NOE selective excitation, and heteronuclear ${ }^{1} \mathrm{H}-{ }^{13} \mathrm{C}$ HMQC-GS long range correlation. Mass-spectral analyses were recorded by DCI/ $\mathrm{NH}_{3}{ }^{+}$with a Nermag R10-10H spectrometer. Elemental analyses were performed with a PerkinElmer 240 analyzer. Analytical TLC was performed on Merck precoated silica gel 60F plates. - Merck silica gel 60 (230-400 mesh) was used for column chromatography

\section{Trioxane 2}

To a stirred solution of $6(13.741 \mathrm{~g}, 0.062 \mathrm{~mol})$ in $\mathrm{MeOH}(100 \mathrm{~mL})$ were added at room temperature, $30 \% \mathrm{H}_{2} \mathrm{O}_{2}(13 \mathrm{~mL}, 0.125 \mathrm{~mol})$ and then, $0.5 \mathrm{M} \mathrm{H}_{2} \mathrm{SO}_{4}$ in $\mathrm{MeOH}(65 \mathrm{~mL}, 0.032 \mathrm{~mol})$ over $5 \mathrm{~min}$. The solution was stirred for $10 \mathrm{~min}$, neutralized with aqueous saturated $\mathrm{NaHCO}_{3}$ and concentrated. The residue was treated with $\mathrm{CH}_{2} \mathrm{Cl}_{2}(100 \mathrm{~mL})$, decanted and the aqueous phase was extracted twice with $\mathrm{CH}_{2} \mathrm{Cl}_{2}(2 \times 50 \mathrm{~mL})$. The combined organic phases were washed two times with water $(2 \times 25 \mathrm{~mL})$, dried over $\mathrm{MgSO}_{4}$ and evaporated to dryness to give a bright yellow oil as a mixture of diastereoisomers $(11.875 \mathrm{~g})$. Yield $46 \%$. Carefully purification by chromatography on silicagel (eluent: petroleum ether / diethylether : 8/2) gave the major diastereomer 2 that could be obtained analytically pure after cristallization in hot heptane. One can note that the others diastereoisomers have not been isolated with a satisfactory purity to be fully characterized.

Major diastereomer 2. (Found C, 66.29; $\mathrm{H}, 8.76 . \mathrm{C}_{14} \mathrm{H}_{22} \mathrm{O}_{4}$ requires $\mathrm{C}, 66.12 ; \mathrm{H}, 8.72 \%$ ); $v \max \left(\mathrm{cm}^{-1)}: 3410,2870,2830,1442,1165\right.$.

${ }^{1} \mathrm{H}$ NMR for $2\left(\mathrm{CDCl}_{3}, 400 \mathrm{MHz}, 298 \mathrm{~K}\right): \delta$, ppm 2.90-2.60 (m, 1H, CH10a), $2.55(\mathrm{~s}, 1 \mathrm{H}, \mathrm{OH}), 2.40-1.90(\mathrm{~m}$, $\left.2 \mathrm{H},-\mathrm{CH}_{2}-\right), 1.80-1.00\left(\mathrm{~m}, 18 \mathrm{H},-\mathrm{CH}_{2}-\right)$. 
${ }^{13} \mathrm{C}$ NMR for $2\left(\mathrm{CDCl}_{3}, 100.6 \mathrm{MHz}, 298 \mathrm{~K}\right): \delta$, ppm 101.9 (C2 or C9), 101.8 (C2 or C9), 72.6 (C5), 42.7(C10a), 35.6, 35.1, 31.7, 31.0, 29.2, 26.5, 25.9, 22.5, 22.3, 19.9.

The two other minor diastereomers were not obtained pure but in a mixture with the major one.

\section{$\mathrm{X}$ ray analysis of 2}

X-Ray data collection. Single crystals of the compound were obtained from n-heptane solution. Data collection were performed at room temperature. Programs used are SHELX $97^{29}$ to solve and refine the structure, and WinGX ${ }^{30}$ package for crystal structure analysis.

Crystal data. $\mathrm{C}_{14} \mathrm{H}_{22} \mathrm{O}_{4}, \mathrm{M}=254.32$, monoclinic, $a=21.864(9), b=6.091(3), c=20.852$ (9) $\AA, \beta=$ $109.83(3)^{\circ}, V=2612$ (2) $\AA^{3}, T=293$ (2) $\mathrm{K}$, space group $C 2 / c\left(\mathrm{n}^{\circ} 15\right), Z=8, \mu \square \mathrm{Mo}-\mathrm{K}_{\alpha} \square=0.093$ $\mathrm{mm}^{-1}, 3849$ reflections measured, 2486 unique $\left(R_{\text {int }}=0.44\right)$. The final $w R\left(F^{2}\right)$ was 0.154 for all data.

\section{Trioxane 8}

A solution of $2(180 \mathrm{mg}, 0.71 \mathrm{mmol})$ and DMAP $(20 \mathrm{mg}, 0.16 \mathrm{mmol})$ in $\mathrm{CH}_{2} \mathrm{Cl}_{2}(5 \mathrm{~mL})$ at $0^{\circ} \mathrm{C}$ was treated with pyridine $(500 \mathrm{mg}, 7.25 \mathrm{mmol})$ and then $\mathrm{Ac}_{2} \mathrm{O}(740 \mathrm{mg}, 7.25 \mathrm{mmol})$. After completion of the reaction at $\mathrm{RT}$, the reactant was destroyed with water $(1 \mathrm{~mL})$ over $1 \mathrm{~h} . \mathrm{CH}_{2} \mathrm{Cl}_{2}(10 \mathrm{~mL})$ was then added and the reaction mixture was washed twice with $1 \mathrm{M}$ aqueous $\mathrm{HCl}(2 \times 5 \mathrm{~mL})$ and then with aqueous $\mathrm{NaHCO}_{3}$ saturated $\left(2 \times 5 \mathrm{~mL}\right.$ ). Organic layer was dried over $\mathrm{MgSO}_{4}$ and evaporated to dryness to give an oil (225 mg) which was purified by flash chromatography on silicagel (eluent: petroleum ether / diethylether : 7/3). Acetate 8 (152 mg) was obtained as an oil. Yield 72\%.

(Found C, 64.76; H, 8.06. $\mathrm{C}_{16} \mathrm{H}_{24} \mathrm{O}_{5}$ requires $\mathrm{C}, 64.87 ; \mathrm{H}, 8.11 \%$ ).

$v \max \left(\mathrm{cm}^{-1)}: 2938,2865,1770,1214,1196,1173,1091,1022\right.$.

${ }^{1} \mathrm{H}$ NMR for $8\left(\mathrm{CDCl}_{3}, 400 \mathrm{MHz}, 298 \mathrm{~K}\right): \delta$, ppm 2.80-2.45 (m,1H, CH10a), 2.40-2.05 (m,1H), 2.00 (s, 3H, $\left.\mathrm{COCH}_{3}\right), \quad 1.90-1.00(\mathrm{~m}, 18 \mathrm{H})$.

${ }^{13} \mathrm{C}$ NMR for $8\left(\mathrm{CDCl}_{3}, 100.6 \mathrm{MHz}, 298 \mathrm{~K}\right): \delta$, ppm 167.4 (CO), 106.6 (C6), 102.4 (C3), 71.7 (C5), 42.7 (C10a), 35.7, 35.2, 32.5, 31.5, 29.1, 26.3, 25.9, 25.1, 22.1, $21.7\left(\mathrm{CH}_{3} \mathrm{CO}\right)$, 18.6.

\section{Trioxane 9}

To a solution of $t$-BuOK (440 mg, $3.92 \mathrm{mmol})$ in anhydrous THF $(6 \mathrm{~mL})$ at $-78^{\circ} \mathrm{C}$ under argon, was added 2 (345 mg, $1.35 \mathrm{mmol})$. One hour after the solubilisation of the substrate, MeI (300 $\mu \mathrm{L}, 4.81$ 
mmol) was added and the reaction left overnight at RT. Aqueous 5\% $\mathrm{NaHCO}_{3}(10 \mathrm{~mL})$ was added and the mixture was extracted twice with $\mathrm{CH}_{2} \mathrm{Cl}_{2}(2 \times 15 \mathrm{~mL})$. The combined organic layers were washed with water $(10 \mathrm{~mL})$, dried over $\mathrm{MgSO}_{4}$ and evaporated to dryness to give an oil $(330 \mathrm{mg})$. Purification by flash chromatography on silicagel (eluent: petroleum ether/ diethylether : 95/5) gave 9 (102 mg) and unreacted $2(215 \mathrm{mg})$. Yield not optimized (28\%). An analytically pure sample of 9 was obtained by vacuum microdistillation.

(Found C, 67.26; H, 9.05. $\mathrm{C}_{15} \mathrm{H}_{24} \mathrm{O}_{4}$ requires $\mathrm{C}, 67.14 ; \mathrm{H}, 9.01 \%$ ).

$v \square \max \left(\mathrm{cm}^{-1)}: \quad 2938,2865,1447,1089,1031\right.$.

$\mathrm{IC}^{+}\left(\mathrm{NH}_{4}^{+}\right) 286\left(25 \%, \mathrm{MNH}_{4}^{+}\right), 269(100 \%, \mathrm{MH}+)$.

${ }^{1} \mathrm{H}$ NMR for $9\left(\mathrm{CDCl}_{3}, 400 \mathrm{MHz}, 298 \mathrm{~K}\right): \delta$, ppm $3.32(\mathrm{~s}, 3 \mathrm{H}), 2.65-2.40(\mathrm{~m}, 1 \mathrm{H}), 2.35-2.05(\mathrm{~m}, 1 \mathrm{H})$, $1.95-1.10(\mathrm{~m}, 17 \mathrm{H}), 0.90-0.70(\mathrm{~m}, 2 \mathrm{H})$.

${ }^{13} \mathrm{C}$ NMR for $9\left(\mathrm{CDCl}_{3}, 100.6 \mathrm{MHz}, 298 \mathrm{~K}\right): \delta$, ppm 104.2, 101.8, 72.9, 49.5, 37.6, 35.6, 35.1, 31.0, $29.1,26.4,25.9,24.0,22.5,21.8,19.9$.

CAUTION: While organic peroxides are potentially explosive compounds and must be handled with safety, these trioxanes were particularly stable.

\section{Alkylation of Mn(TPP) by 2 in the presence of borohydride}

$\mathrm{Mn}^{\mathrm{III}}(\mathrm{TPP}) \mathrm{Cl}(18 \mathrm{mg}, 25.6 \mu \mathrm{mol}, 1$ equiv) and $2(20 \mathrm{mg}, 78.7 \mu \mathrm{mol}, 3$ equiv) were dissolved in dichloromethane $(3 \mathrm{~mL})$. This solution was degassed and kept under an argon atmosphere. Tetra- $n$ butylammonium borohydride (78 mg, $303 \mu \mathrm{mol}, 12$ equiv) was added as a solid. The mixture was stirred at room temperature. After 2 hrs, the manganese(II) macrocyclic complex was demetallated in situ. For this purpose, a degassed solution of cadmium(II) nitrate tetrahydrate $(212 \mathrm{mg}, 687 \mu \mathrm{mol}, 27$ equiv) in DMF $(1.8 \mathrm{~mL})$ was added and stirring was continued for $10 \mathrm{~min}$ in order to allow the transmetallation of the complex from manganese(II) to cadmium(II). Dichloromethane (10 $\mathrm{mL})$ was then added under air, and this solution was treated with aqueous acetic acid $(10 \mathrm{vol} \%, 10 \mathrm{~mL})$ to demetallate the cadmium(II) complex. The organic layer was washed with $1 \mathrm{M}$ sodium acetate (3 times), and dried on sodium sulfate. Purification on a column of neutral alumina (grade II-III), eluted with a mixture dichloromethane/hexane (from 50/50 to $80 / 20 \mathrm{v} / \mathrm{v}$ ) afforded a mixture of the chlorin and porphyrin adducts $15 \mathrm{C}$ and $\mathbf{1 5 P}$, respectively. 
Analysis of the mixture $15 C+15 P$.

TLC $\left(\mathrm{SiO}_{2}\right.$, ethyl acetate/hexane 30/70 v/v): $\mathrm{R}_{\mathrm{f}} 0.48$ (15C, major), 0.42 (15P, minor).

UV-vis in $\mathrm{CH}_{2} \mathrm{Cl}_{2}: \lambda_{\max }$ (relative intensity) 372 (14), 420 (100), 518 (6), 546 (4), 598 (2), 652 (11).

MS (DCI/ $\left.\mathrm{NH}_{3}{ }^{+}\right): m / z$ (relative intensity) $851\left(19, \mathrm{MH}^{+}\right.$for 15P), 852 (18), $853\left(100, \mathrm{MH}^{+}\right.$for $\mathbf{1 5 C}$ ),

854 (63), 855 (23), 856 (6). Proportion of $\mathbf{1 5 P}=19 /(100+19) \times 100=16 \%$.

In order to get the single adduct $\mathbf{1 5 P}$, the mixture $15 \mathrm{C}+\mathbf{1 5 P}$ was oxidized by 2,3-dichloro5,6-dicyanobenzoquinone in refluxing dichloromethane for $20 \mathrm{~min}$. The organic layer was washed three times with aqueous $\mathrm{NaOH}(\mathrm{pH} 8)$, and dried with sodium sulfate. The adduct 15P was purified by chromatography on neutral alumina grade II-III, with ethyl acetate/hexane 20/80 v/v as eluent.

${ }^{1} \mathrm{H}$ NMR for 15P $\left(\mathrm{CD}_{2} \mathrm{Cl}_{2}, 250.13 \mathrm{MHz}, 298 \mathrm{~K}\right): \delta$, ppm 8.92, 8.89, 8.79, 8.75, 8.69, and $8.41(6 \mathrm{x} \mathrm{d}, 6$ x $1 \mathrm{H},{ }^{3} J=5 \mathrm{~Hz}, \beta$-pyrrolic-H), 8.86 (br s, $1 \mathrm{H}, \mathrm{H} 3$ '), 8.27-8.20 (8H, phenyl-H), 7.85-7.75 (12H, phenylH), 3.63 (H10a), 2.63-1.20 (unresolved m, 20H, $-\mathrm{CH}_{2}-$ ), -2.86 , and -2.67 ( 2 x br s, 2 x 1H, NH). For full NMR characterization of 15P, see next paragraph.

\section{Alkylation of Mn(TPP) by 2 in the presence of borodeuteride}

$\mathrm{Mn}^{\mathrm{III}}(\mathrm{TPP}) \mathrm{Cl}(37.5 \mathrm{mg}, 53.3 \mu \mathrm{mol}, 1$ equiv) and 2 (40 mg, $157.5 \mu \mathrm{mol}, 3$ equiv) were dissolved in dichloromethane $(5.5 \mathrm{~mL})$. This solution was degassed and kept under an argon atmosphere. Tetra- $n$ butylammonium borodeuteride (130 mg, $498 \mu \mathrm{mol}, 9$ equiv) was added as a solid. The mixture was stirred at room temperature for $2 \mathrm{hrs}$. A degassed solution of cadmium(II) nitrate tetrahydrate (300 mg, $972 \mu \mathrm{mol}, 18$ equiv) in DMF ( $2 \mathrm{~mL}$ ) was added and stirring was continued for $15 \mathrm{~min}$. Aqueous acetic acid $(10$ vol\%, $10 \mathrm{~mL})$ and dichloromethane $(20 \mathrm{~mL})$ were added under air. The organic solution was washed with water (5 times), and dried on sodium sulfate. As observed when borohydride was used as reductant, UV-vis analysis and TLC indicated that chlorin adduct was the major one. The dichloromethane solution $(3 \mathrm{~mL})$ of adducts was treated with 2,3-dichloro-5,6-dicyanobenzoquinone (117 mg, $515 \mu \mathrm{mol}, 10$ equiv), at reflux for $40 \mathrm{~min}$. The organic layer was washed four times with aqueous $\mathrm{NaOH}(\mathrm{pH}$ ), and dried with sodium sulfate. Purification was obtained by chromatography on neutral alumina grade II-III, with ethyl acetate/hexane from $5 / 95$ to $30 / 70 \mathrm{v} / \mathrm{v}$ as eluent. The solvents were eliminated under vacuum. Yield $=8 \mathrm{mg}(18 \%$ with respect to starting $\mathrm{Mn}(\mathrm{TPP}) \mathrm{Cl})$.

UV-vis in $\mathrm{CH}_{2} \mathrm{Cl}_{2}$ : $\lambda_{\max }$ (relative intensity) 420 (100), 518 (5.6), 552 (2.8), 596 (2.3), 648 (2). 
MS (DCI/ $\left.\mathrm{NH}_{3}{ }^{+}\right): m / z$ (relative intensity) $850(10), 851\left(100, \mathrm{MH}^{+}\right.$for $\left.15 \mathrm{P}\right), 852\left(84, \mathrm{MH}^{+}\right.$for $\left.\mathbf{1 5 P}-\boldsymbol{d}\right)$, 853 (43), 854 (25), 855 (16). Proportion of 15P- $\boldsymbol{d}=14 \%$, calculated from $\mathrm{m} / z=851$ and 852 (taking also in account the isotopic contribution of $\mathbf{1 5 P}$ in the peak at $m / z=852$ ).

IR (KBr pellet): $v_{\mathrm{CO}}=1729 \mathrm{~cm}^{-1}$ (band width $\left.=20 \mathrm{~cm}^{-1}\right)$; IR (dichloromethane): $v_{\mathrm{CO}}=1725$, and 1719 $\mathrm{cm}^{-1}$ (poorly defined).

NMR for 15P + 15P- $\boldsymbol{d}$. For clarity, the signals of the porphyrin moiety are described first, and than that of the drug fragment (see Scheme 5 for the numbering of carbon atoms).

${ }^{1} \mathrm{H}$ NMR for $\mathbf{1 5 P}+\mathbf{1 5 P}-\boldsymbol{d}\left(\mathrm{CD}_{2} \mathrm{Cl}_{2}, 500.13 \mathrm{MHz}, 298 \mathrm{~K}\right): \delta$, ppm 8.90, 8.87, 8.79, 8.76, 8.69, and 8.39 (6 x d, $6 \times 1 \mathrm{H},{ }^{3} J=5 \mathrm{~Hz}, \beta$-pyrrolic-H), 8.82 (br s, $\underline{0.9 \mathrm{H}}, \mathrm{H} 3$ '), 8.25-8.20 (8H, Phenyl-H), 7.83-7.74 (12H, Phenyl-H), -2.79 , and -2.59 ( 2 x br s, 2 x 1H, NH), 3.53 (m, 1H, H10a), $1.86\left(2 \mathrm{H}, \mathrm{H}_{2} \mathrm{C} 10\right), 1.34$ and $1.25\left(\mathrm{H}_{2} \mathrm{C} 9\right), 1.90$ and $1.50\left(\mathrm{H}_{2} \mathrm{C} 8\right), 2.49$ and $2.22\left(\mathrm{H}_{2} \mathrm{C} 7\right), 2.46$ and $1.66\left(\mathrm{H}_{2} \mathrm{C} 12\right), 2.02$ and 1.99 $\left(\mathrm{H}_{2} \mathrm{C} 11\right), 2.44$ and $1.25\left(\mathrm{H}_{2} \mathrm{C} 13\right), 1.88$ and $1.67\left(\mathrm{H}_{2} \mathrm{C} 14\right), 2.12$ and $1.66\left(\mathrm{H}_{2} \mathrm{C} 15\right), 2.59$ and 2.34 $\left(\mathrm{H}_{2} \mathrm{C} 16\right)$. The chlorin adduct $15 \mathrm{C}$ was present as contaminant $[10 \mathrm{~mol} \%,-1.41 \mathrm{ppm}(\mathrm{NH})]$.

${ }^{13} \mathrm{C}$ NMR for 15P + 15P- $\boldsymbol{d}\left(\mathrm{CD}_{2} \mathrm{Cl}_{2}, 125.7 \mathrm{MHz}, 298 \mathrm{~K}\right): \delta$, ppm $150.9(\mathrm{C} 2$ '), 34.9 (C10a), $32.8(\mathrm{C} 10)$, 25.9 (C9), 22.9 (C8), 37.1 (C7), 174.3 (C3), 86.4 (C5), 26.3 (C12), 30.7 (C11), 37.1 (C13), 21.4 (C14), 29.4 (C15), 39.3 (C16), 209.3 (C6).

Acknowledgements. Dr Yannick Coppel, from the LCC-CNRS, is gratefully acknowledged for accurate NMR characterization of the covalent adduct 15P.

\section{References}

1. (a) M. Balter, E. Marshall, Science, 2000, 290, 428-430. (b) E. Marshall, Science, 2000, 290, $437-439$

2. P. Newton, N. White, Annu. Rev. Med., 1999, 50, 179-192.

3. S. Pagola, P. W. Stephens, D. S. Bohle, A. D. Kosar, S. K. Madsen, Nature, 2000, 404, $307-$ 310.

4. S. R. Meshnick, T. E. Taylor, S. Kamchonwongpaisan, Microbiol. Rev., 1996, 60, 301-315. 
5. G. H. Posner, C. H. Oh, D. Wang, L. Gerena, W. K. Milhous, S. R. Meshnick, W. Asawamahasakda, J. Med. Chem., 1994, 37, 1256-1258.

6. Y.-L. Hong, Y.-Z. Yang, S. R. Meshnick, Mol. Biochem. Parasitol., 1994, 63, 121-128.

7. J. Bhisutthibhan, X.-Q. Pan, P. A. Hossler, D. J. Walker, C. A. Yowell, J. Carlton, J. B. Dame, S. R. Meshnick, J. Biol. Chem., 1998, 273, 16192-16198.

8. (a) A. Robert, B. Meunier, J. Am. Chem. Soc., 1997, 119, 5968-5969. (b) A. Robert, A. B. Meunier, Chem. Eur. J., 1998, 4, 1287-1296.

9. J. Cazelles, A. Robert, B. Meunier, J. Org. Chem., 2002, 67, 609-619.

10. A. Robert, O. Dechy-Cabaret, J. Cazelles, B. Meunier, Acc. Chem. Res., 2002, 35, 167-174.

11. (a) A. Robert, J. Cazelles, B. Meunier, Angew. Chem. Int. Ed., 2001, 40, 1954-1957. (b) A. Robert, Y. Coppel, B. Meunier, Chem. Commun., 2002, 414-416.

12. S. Kamchonwongpaisan, C. Nilanonta, B. Tarnchompoo, C. Thebtaranonth, Y. Thebtaranonth, Y. Yuthavong, P. Kongsaeree, J. Clardy, Tetrahedron Lett., 1995, 36, 1821-1824.

13. H. J. Roth, C. Schwenke, G. Dvorak, Arch. Pharm., 1965, 298, 326-336.

14. (a) C. Mannich, Ber., 1941, 74B, 557-564. (b) E. Warnhoff, W. Johnson, J. Am. Chem. Soc., 1953, 75, 496-497.

15. (a) J. Kice, L. Mullan, J. Am. Chem. Soc., 1976, 98, 4259-4268. (b) J. Dixon, T. Bruice, J. Am. Chem. Soc., 1971, 93, 6592-6597. (c) J. Edwards, R. Pearson, J. Am. Chem. Soc., 1962, 84, 16-24.

16. M. Carreiras, B. Rodriguez, R. Lopez-Garcia, R. A. Rabanal, Phytochemistry, 1987, 26, 33513353.

17. E. Kolehmainen, K. Rissanen, K. Laihia, P. Malkavaara, J. Korvola, R. Kauppinen, J. Chem. Soc. Perkin Trans. 2, 1993, 3, 437-439.

18. Y. Hamada, H. Tokuhara, A. Masuyama, M. Nojima, M.; H.-S. Kim, K. Ono, N. Ogura, Y. Wataya, J. Med. Chem., 2002, 45, 1374-1378.

19. L. Cointeaux, J.-F. Berrien, V. Peyrou, O. Provot, L. Ciceron, M. Danis, A. Robert, B. Meunier, J. Mayrargue, Bioorg. Med. Chem. Lett., 2003, 13, 75-77.

20. G. Höfle, W. Steglich, H. Vorbrüggen, Angew. Chem., Int. Ed. Engl., 1978, 17, 569-583. 
21. A. L.Baumstark, P. C. Vasquez, Y.-X. Chen, J. Org. Chem., 1994, 59, 6692-6696.

22. (a) P. Dussault, X. Liu, Org. Lett., 1999, 1, 1391-1393. (b) P. Dussault, A. Sahli, T. Westermeyer, J. Org. Chem., 1993, 58, 5469-5474. (c) B. Snider, Z. Shi, J. Org. Chem., 1990, 55, 5669-5671. (d) J. Yoshida, S. Nakatani, K. Sakagughi, S. Isoe, J. Org. Chem., 1989, 54, 3383-3389.

23. P. Mirovsky, F. Gay, D. Bustos, D. Mazier, M. Gentilini, Trans. R. Soc. Trop. Med. Hyg., 1990, 84, 511-515.

24. for example see: G. H. Posner, H. B. Jeon, M. H. Parker, M. Krasavin, I. H. Paik T.A. Shapiro, J. Med. Chem., 2001, 44, 3054-3058 ; D.S. Turok, H. Ziffer, J. Med. Chem., 1995, 38, 5045-504 ; C.W. Jefford, J.A. Velarde, G. Bernardinelli, D.H. Bray, D.C. Warhust, W.K. Milhous, Helv. Chim. Acta, 1993, 76, 2775-2788 ; A. J. Lin, A. B. Zikry, D. E. Kyle, J. Med. Chem., 1997, 40, 1396-1400, and references cited herein.

25. O. Provot, B. Camuzat-Dedenis, M. Hamzaoui, H. Moskowitz, J. Mayrargue, A. Robert, J. Cazelles, B. Meunier, F. Zouhiri, D. Desmaële, J. d'Angelo, J. Mahuteau, F. Gay, L. Ciceron, Eur. J. Org. Chem. 1999, 1935-1938.

26. R. D. Sands,. J. Org. Chem., 1994, 59, 468-471.

27. W. Trager, J. B. Jensen, Science, 1976, 193, 673-675.

28. R. E. Desjardins, C. J. Canfield, J. D. Haynes, J. D. Chulay, Antimicrob. Agents Chemother., $1979,16,710-718$.

29. G. Sheldrick, SHELX97. Programs for Crystal Structure Analysis, 1997. University of Göttingen, Germany.

30. L. Farrugia, J. Appl Cryst., 1999, 32, 837-838. 


\section{Captions}

Scheme 1. Structures of the antimalarial artemisinin 1, and model peroxides $\mathbf{2}$ and $\mathbf{3}$.

Scheme 2. Synthesis of the trioxanes $\mathbf{2}, \mathbf{8}$, and $\mathbf{9}$. (Only one enantiomer is depicted)

Scheme 3. Reaction of cedronellone with $\mathrm{H}_{2} \mathrm{O}_{2}$.

Scheme 4. Ortep drawing of the trioxane 2.

Scheme 5. Reductive activation of the trioxane $\mathbf{2}$ by the heme model $\mathrm{Mn}^{\mathrm{II}} \mathrm{TPP}$, leading to the covalent adducts $\mathbf{1 5 C}$ and $\mathbf{1 5 P}$. (Only one enantiomer is depicted)

Scheme 6. Reductive activation of the trioxane 2 by $\mathrm{Mn}^{\mathrm{II}} \mathrm{TPP}$ in the presence of borodeuteride. (Only one enantiomer is depicted)

Table 1. In vitro antimalarial activity of trioxanes 2, 8, and 9 against the Plasmodium falciparum $\mathrm{H}$ strain.

Table 2. Selected data from X-ray diffraction analysis of trioxane $\mathbf{2}$. 

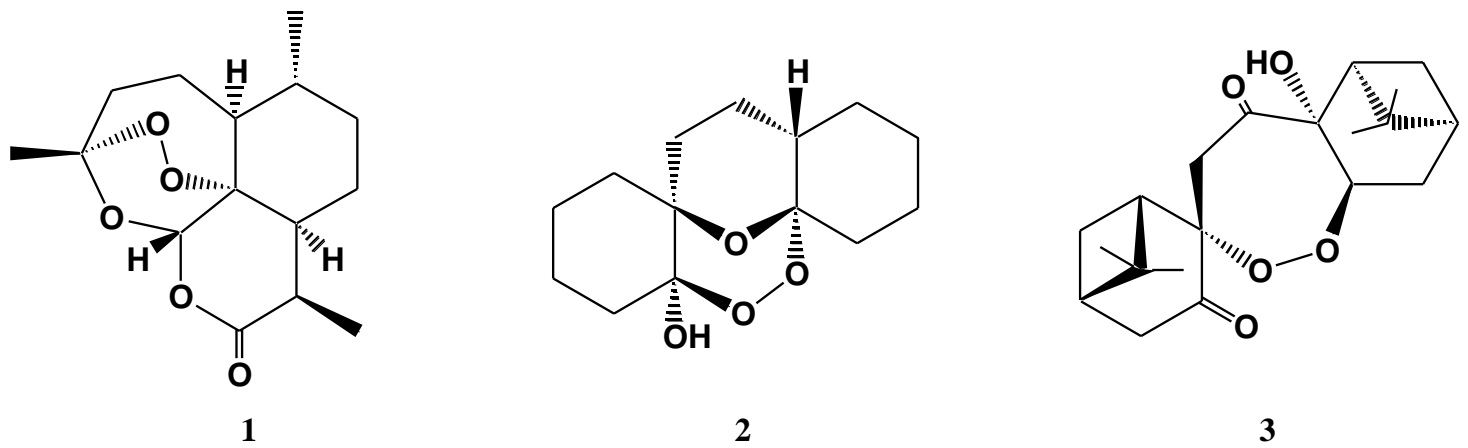

Scheme 1 

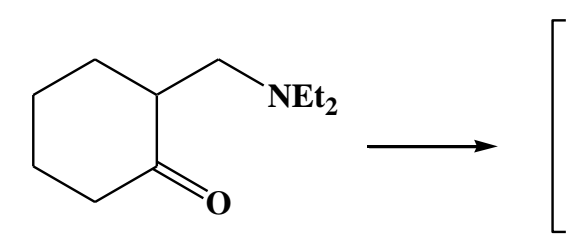<smiles>C=C1CCCCC1=O</smiles>

5<smiles></smiles>

4<smiles>OC12CCCCC13CCC1CCCCC1(O2)O3</smiles>

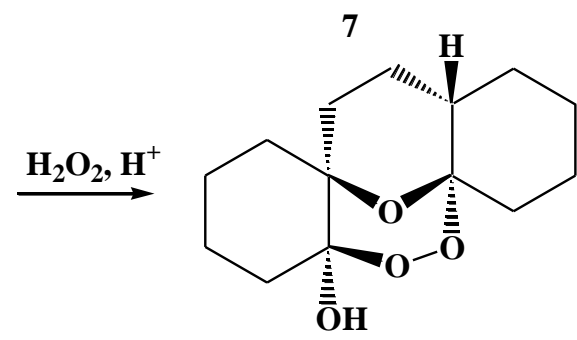

2

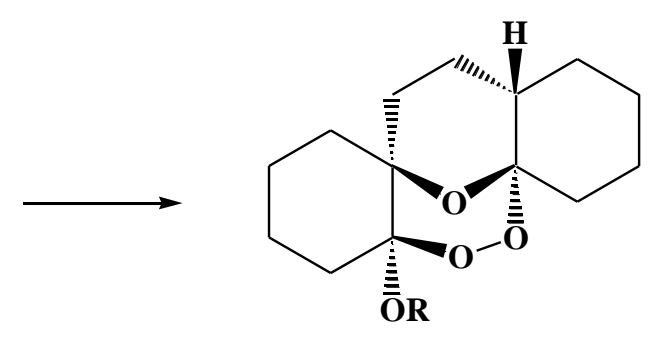

$8 \mathrm{R}=\mathrm{Ac} ; 9 \mathrm{R}=\mathrm{Me}$

Scheme 2 


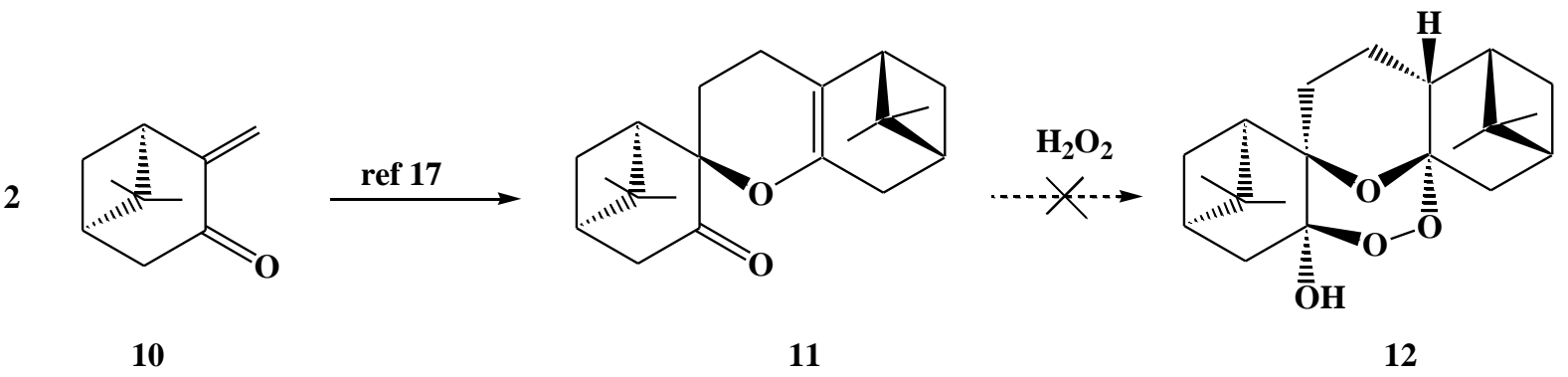

Scheme 3 

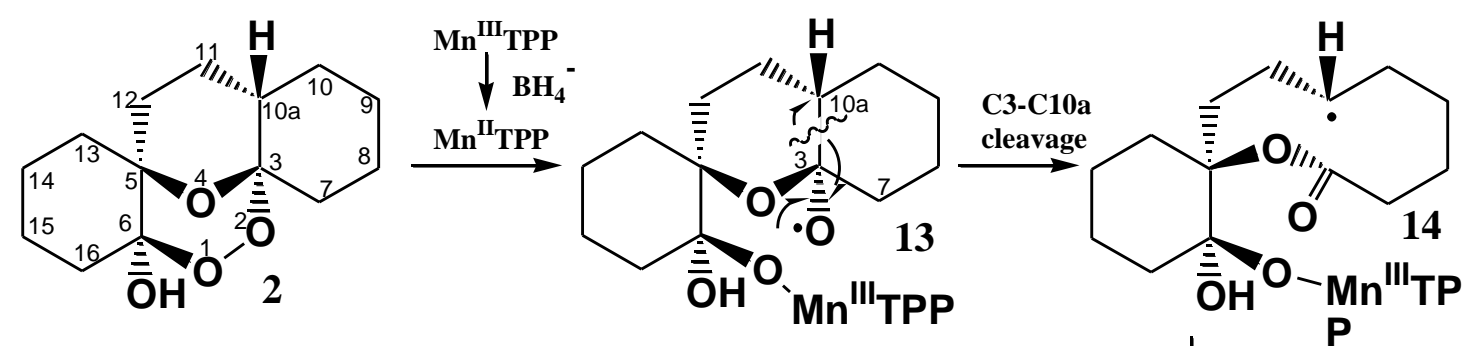

1. Alkylation at C2'

2. Intramolecular electron transfer from C3' to Mn

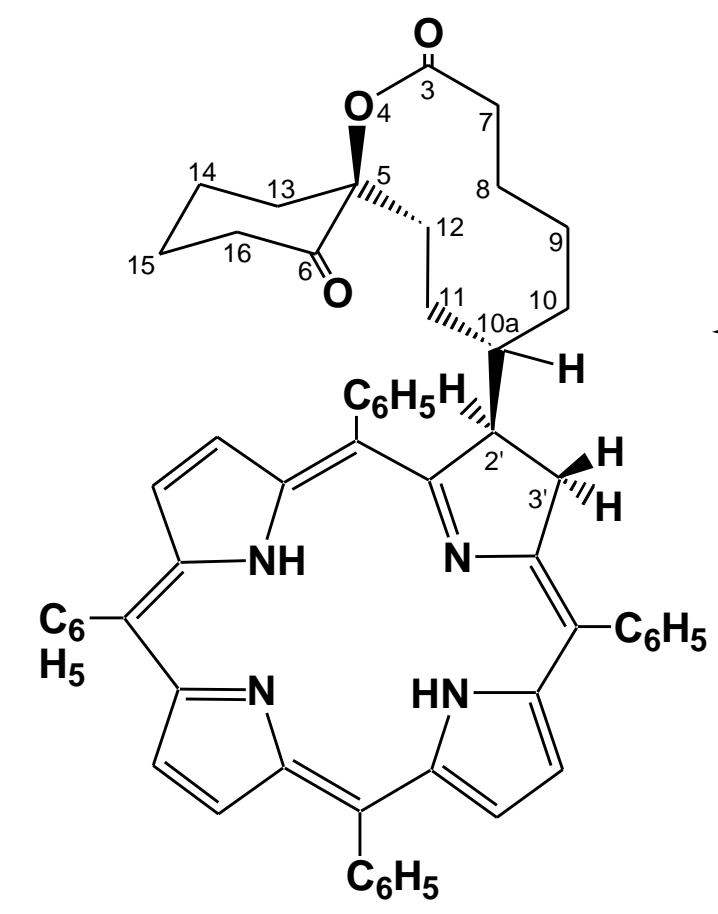

15C

Chlorin adduct

$\mathrm{C}_{58} \mathrm{H}_{52} \mathrm{~N}_{4} \mathrm{O}_{3}$

$\mathrm{MW}=\mathbf{8 5 2 . 4}$
1. Trapping by $\mathrm{BH}_{4}$

2. Demetallation

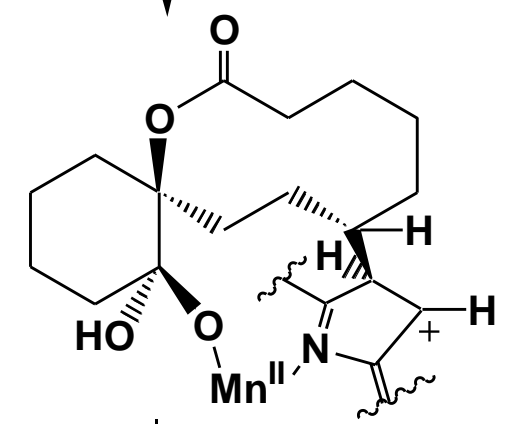

1. $\mathrm{H}^{+}$elimination at $\mathrm{C2}^{\prime}$

2. Demetallation

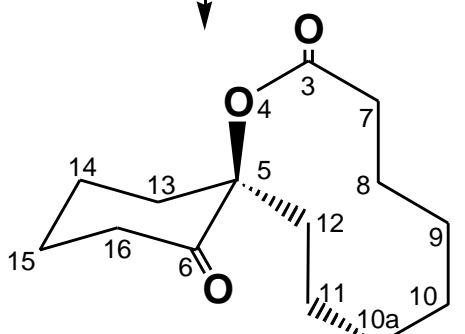

15P

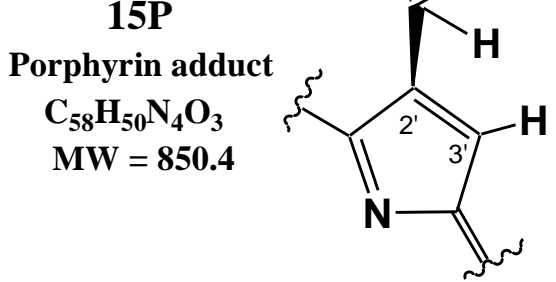

Scheme 5 


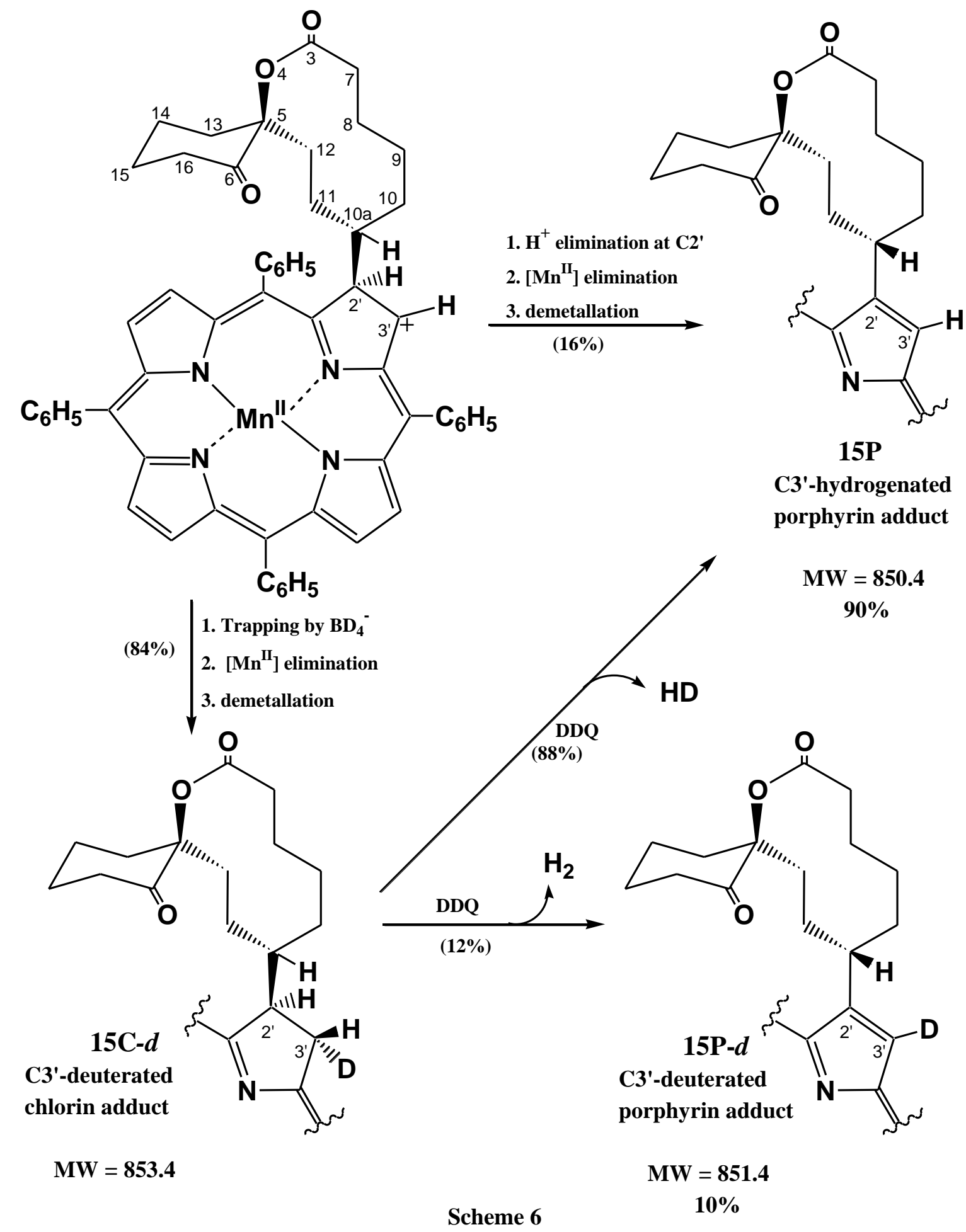




\begin{tabular}{|c|c|c|c|c|c|}
\hline Compounds & 2 & 8 & 9 & Artemether & Chloroquine \\
\hline IC 50 $\left(\mathrm{nmolL}^{-1}\right)$ & 320 & $>5000$ & $>5000$ & 4.1 & 15 \\
\hline
\end{tabular}

Table 1: In vitro antimalarial activity of trioxanes $\mathbf{2 , 8}$ and $\mathbf{9}$ against $P$. falciparum $\mathrm{H}$ strain. 


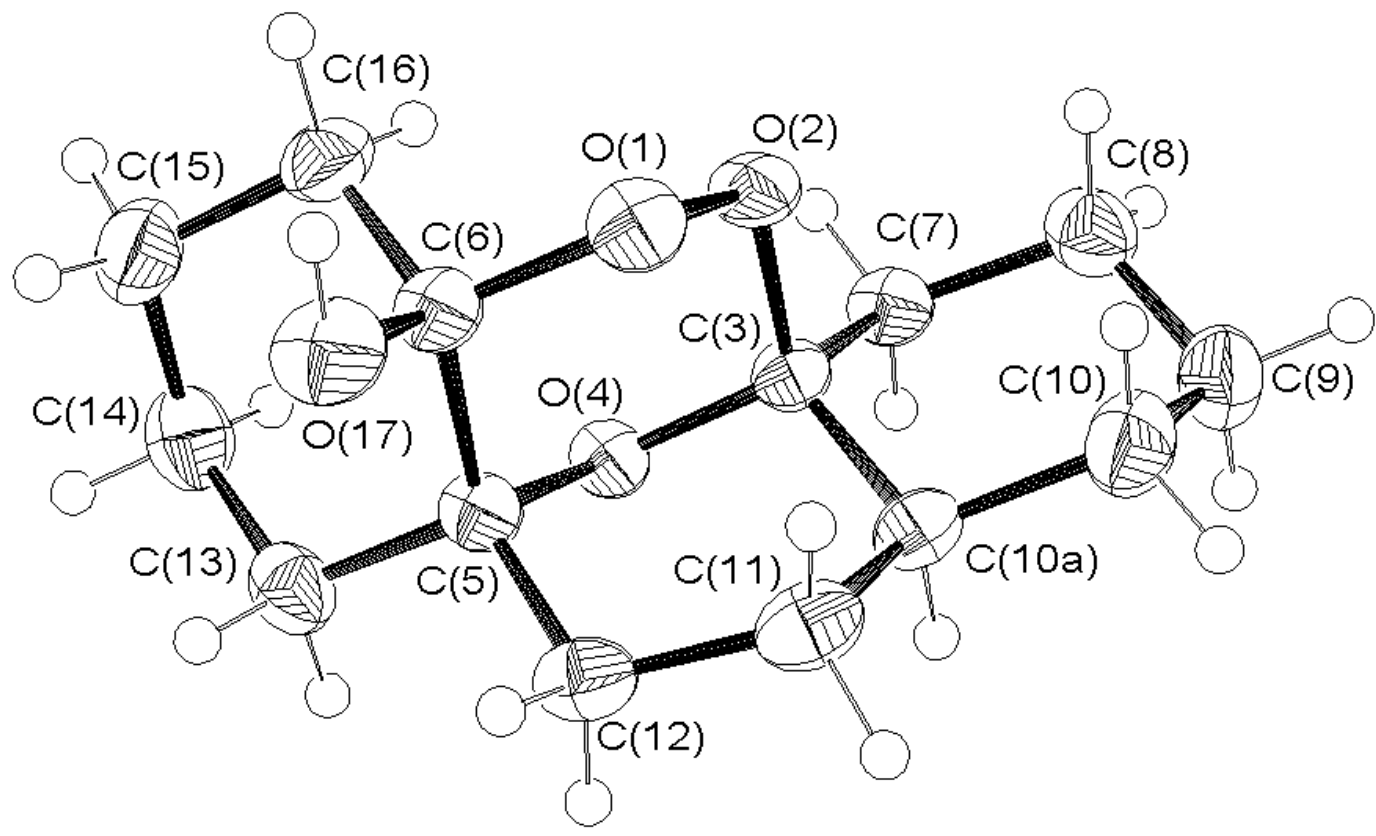

Scheme 4 Ortep drawing of molecule 2 at $50 \%$ probability level 
Table 2 Selected angles $\left(^{\circ}\right)$

\begin{tabular}{lclc}
\hline $\mathrm{C}(7)-\mathrm{C}(3)-\mathrm{O}(2)$ & $101.8(2)$ & $\mathrm{C}(10)-\mathrm{C}(3)-\mathrm{O}(2)$ & $114.8(2)$ \\
$\mathrm{O}(1)-\mathrm{C}(6)-\mathrm{O}(17)$ & $102.6(2)$ & $\mathrm{C}(5)-\mathrm{C}(13)-\mathrm{C}(14)$ & $114.3(2)$ \\
$\mathrm{C}(13)-\mathrm{C}(5)-\mathrm{O}(4)$ & $106.0(2)$ & $\mathrm{C}(5)-\mathrm{C}(12)-\mathrm{C}(11)$ & $114.2(2)$ \\
\hline
\end{tabular}

